\title{
Use of Wood Characters in the Identification of Terminalia spp in Sri Lanka
}

\author{
Ruwanpathirana N.D.* \\ Research \& Training Division, State Timber Corporation, Sampathpaya, Battaramulla, Sri Lanka \\ "nimalruwan@gmail.com
}

\begin{abstract}
More than 250 timber species are being used by the timber industry in Sri Lanka, among the major timber consumers are housing developer, furniture manufacturer and wood fabricators. Once the tree is felled, the identification of the tree become very difficult and need to rely on their macroscopic/ microscopic features and physical properties of timber. Timber identification is necessary for right use of timber and to check on fraud in timber trading as some timber traders mix or sell low price, different type of timber species, deceiving customers to increase their profit margin.
\end{abstract}

Five timber species of Terminalia namely Terminalia arjuna (Kumbuk), Terminalia bellirica (Bulu), Terminalia catappa (Kottamba), Terminalia chebula (Aralu) and Terminalia parviflora (Hampalanda) of the family of Combretaceae were studied anatomically in search of sufficient features by which one Terminalia sp can be separated from the other. The examination of the transverse section of wood with a hand lens (x25) does not provide adequate reliable information to differentiate one species from the other for identification due to resemblance of wood structure of five Terminalia spp. Hence for the anatomical examination, transverse section (T.S.), radial longitudinal section (R.L.T.) and tangential longitudinal section (T.L.S.) were obtained using the microtome.

In this study, some important wood anatomical and non anatomical features were studied according to IAWA (1989). It was found that all the Terminalia spp had diffuse porous wood having vessels mainly solitary and occasionally in $2-3$ vessels of radial multiples. Mean vessel diameter and vessel diameter range were recorded respectively as $241 \mu \mathrm{m}$ and 172$331 \mu \mathrm{m}$ in Terminallia arjuna, $169 \mu \mathrm{m}$ and 107-204 $\mu \mathrm{m}$ in Terminalia bellirica , $240 \mu \mathrm{m}$ and 169-309 $\mu \mathrm{m}$ in Terminallia catappa, $115 \mu \mathrm{m}$ and 68-175 $\mu \mathrm{m}$ inTerminalia chebula and $124 \mu \mathrm{m}$ and 75-159 $\mu \mathrm{m}$ in Terminalia parviflora. Mean vessel frequency were observed as 3 per $\mathrm{mm}^{2}$ in Terminallia arjuna, 4 per $\mathrm{mm}^{2}$ in Terminalia bellirica, 3 per $\mathrm{mm}^{2}$ in Terminallia catappa, 6 per $\mathrm{mm} 2$ in Terminalia chebula and 5 per $\mathrm{mm}^{2}$ in Terminalia parviflora. Mean rays frequency, mean ray height and mean ray width were found respectively as 9 per mm, $206 \mu \mathrm{m}, 24 \mu \mathrm{m}$ in Terminallia arjuna, 11 per mm, $\mu \mathrm{m} 283,24$ $\mu \mathrm{m}$ in Terminalia bellirica, 8 per mm, $280 \mu \mathrm{m}, 25 \mu \mathrm{m}$ in Terminallia catappa, 13 per mm, $239 \mu \mathrm{m}, 31 \mu \mathrm{m}$ in Terminalia chebula and 10 per $\mathrm{mm}, 235 \mu \mathrm{m}, 30 \mu \mathrm{m}$ in Terminalia parviflora. Ray cell arrangement is mostly uniseriate and occasionally byseriate in Terminalia bellirica, Terminalia parviflora, Terminallia arjuna. Ray cell arrangement is mostly multiseriate and occasionally uniseriate in Terminallia catappa. Terminalia chebula has uniseriate ray cell arrangment.

Different type of axial parenchyma types were found in each terminalia species from which the prominent type of axial parenchyma was identified from each species as follows; Terminalia bellirica had axial parenchyma band (more than three cells wide). Terminalia 
parviflora and Terminalia catappa had aliform/ vasicentric type axial parenchyma which can be differentiated from confluent parenchyma type in Terminalia chebula. Vasicentric (halo) parenchyma typewere found mainly in Terminallia arjuna. Finaly, it can be concluded that ray cell arrangement and axial parenchyma types can be used together as baseline to distinguish Terminalia spp in Sri Lanka for the purpose of timber identification.

Keywords: Wood characters, Terminalia spp 